\title{
COMMENT
}

\section{COVID-19 Pandemic and Bangladesh}

\author{
Chowdhury MAJ
}

COVID-19 is now a pandemic, as the WHO Director General Tedros Adhanom Ghebreyesus declared during a media briefing on Wednesday, 11 March, 2020. ${ }^{1}$

Bangladesh situation as on 27 March, 2020, total affected 44 out of which died 5. Some of them have returned from abroad and others had come in contact with those coming from abroad. So, community spread has already been started. $1^{\text {st }}$ three cases detected on 8 March and $1^{\text {st }}$ death declared on $18^{\text {th }}$ March, 2020. ${ }^{2}$

Government steps: Lockdown in Shibchar Upazilla of Madaripur district on $19^{\text {th }}$ March. In Shibchar Upazilla only 664 people came from abroad in the recent past. Few other places are been lockdown locally. All schools remain closed since $18^{\text {th }}$ March. All religious, political, social and cultural functions are prohibited. Government has already declared 10 days holiday in all Govt. and non-Govt. organisations which started from $26^{\text {th }}$ March. Army has been called to help civil administrations so that people maintain social distancing and home quarantine in true sense. ${ }^{3}$ Lab facilities to detect corona virus infection have been increased. PPEs to doctors and health care workers are being distributed though at this moment are not sufficient.

Early detection of the cases and isolation at this moment is the most important aspect of the control of the epidemic, though proper quarantine of the people coming from abroad should have been the most effective way to control the disease. As per DGHS from 7 to 21 March 1, 72,362 people entered Bangladesh from abroad through different routes. Amongst them, 17558 has been under quarantine. ${ }^{4}$ Rests of them are moving freely. To find out all of them and made under quarantine is the most challenging job. Moreover, those under quarantine many of them are not following the proper rules of quarantine.

Global situation: By the 26 $6^{\text {th }}$ March 2020 midnight 175 countries have been affected, total affected about 5 lacs and total death more than 22 thousands. Total death exceeds the china in Italy. USA seems to be next epicentre of pandemic.

* Correspondence: Dr. Md. Abdul Jalil Chowdhury, Department of Internal Medicine; Bangabandhu Sheikh Mujib Medical University (BSMMU), Dhaka, Bangladesh; e-mail: majchow@yahoo.com; ORCID: 0000-00020003-3703-3212
The global situation is becoming grave day by day. We don't know the exact nature of the virus. Is it the same that started in Wuhan of China? It is said that virus is going for repeated mutations as the days pass. So, side by side research on the already detected viruses should be started. We think in Bangladesh there are laboratories in different institutes and universities who can do research on the novel corona virus. It needs coordinated approach and government facilitations.

It is no doubt that whatever may be the size of epidemic here in Bangladesh there will be a huge impact on economy worldwide. We think government and others linked with it are quite aware of the impending problem.

Not only that there will be huge impact on economy but there will be great impact on mental health of the people. This has to be kept in mind. We have to cope with the current epidemic with all our efforts but at the same time we have to be ready for the future anticipated problems.

Protection of the HCW: Government should take more vigorous measures to protect their Healthcare workers. Not only that those who are involved in the management of the corona virus are supplied with the personal protection equipment they should be sufficient in numbers and supply should be constant. Treating doctors should have the access to the laboratory so that they can test the suspected cases as early as possible before many are contracted. They should have the incentives in any form so that they are encouraged to their job without hesitation.

WHO is not happy with the actions taken by the governments in many less affected countries. They are constantly warning against the havoc that have to face in future if timely appropriate measures are not taken. WHO says that many countries including Bangladesh have got the $2^{\text {nd }}$ chance to strengthen the preventive measures. They have provided with the six advices to be followed. We think government should take the advice given by WHO director General Tedros Adhanom Ghebreyesus on the $25^{\text {th }}$ March 2020 very seriously and acts appropriately. 


\section{Reference}

1. WHO. WHO Director-General's opening remarks at the media briefing on COVID-19 - 11 March 2020. World HO. Geneva.

url: www.who.int/ dg/speeches/ detail/whodirector-general-s-opening-remarks-at-the-mediabriefing-on-covid-19-11-march-2020.
2. IEDCR. Institute Epidemiology Disease Control and Research. Dhaka. www.iedcr.gov.bd

3. Ministry of Public Adminstration. Dhaka, Bangladesh. https://mopa.gov.bd/

4. DGHS. Directorate General of Health Services. Dhaka, Bangladesh. www.dghs.gov.bd 